\title{
IDENTIFIKASI KEANEKARAGAMAN DAN DOMINASI SERANGGA PADA TANAMAN BUNGA MATAHARI (Helianthus annuus L.) DENGAN TEKNIK YELLOW TRAP
}

\author{
Identification of Diversity and Domination of Insects in Sunflower Plants \\ (Helianthus annuus L.) with the Yellow Trap Technique \\ Isna Tustiyani*, Vidiya Fitri Utami, Atak Tauhid \\ Program Studi Agroteknologi, Fakultas Pertanian, Universitas Garut \\ *email: isnatustiyani@gmail.com
}

\begin{abstract}
ABSTRAK
Penelitian bertujuan untuk mengetahui keanekaragaman jenis dan peran serangga serta serangga yang mendominasi pada tanaman bunga matahari (Helianthus annuus L.). Penelitian dilaksanakan di Kampung Sindang Sari, Kecamatan Leles Kabupaten Garut dari Bulan Mei hingga Juli 2019. Penelitian ini menggunakan metode kualitatif pada lahan penelitian dengan pemasangan perangkap serangga yaitu yellow trap sebanyak 12 trap yang ditentukan polanya secara acak dan pengamatan secara visual saat di lahan penelitian. Hasil penelitian menunjukan bahwa terdapat 9 ordo serangga yaitu ordo Diptera, Hymenoptera, Coleoptera, Hemiptera, Lepidoptera, Araneae, Odonata, Orthoptera, dan Isoptera. Serangga yang berperan sebagai hama terdapat 5 ordo yaitu Diptera, Hemiptera, Lepidoptera, Orthoptera, Isoptera, dan serangga yang berperan sebagai musuh alami terdapat 3 ordo yaitu Ordo Odonata, Coleoptera, Araneae, sedangkan ordo Hymenoptera termasuk kedalam musuh alami dan sebagai serangga penyerbuk (pollinator) dan serangga yang mendominasi yaitu ordo Diptera sebanyak 3223 serta indeks keanekaragaman serangga 1,0123733 memiliki nilai tolak ukur sedang dan indeks dominasi serangga 0,439025297 dengan nilai tolak ukur rendah.
\end{abstract}

Kata Kunci : Indeks Keanekaragaman serangga, Indeks Dominasi Seangga, Yellow trap, bunga matahari (Helianthus annuus L.)

\begin{abstract}
This study aims to determine the diversity of species and the role of insects and insects that dominate in sunflower plants (Helianthus annuus L.). The study was conducted in Sindang Sari Village, Leles, Garut from May to July 2019. The study used a qualitative method in the research area by installing 12 of insect traps namely yellow traps which were randomly determined patterns and observations visually while in the research field. The results showed there were 9 insect orders namely Diptera, Hymenoptera, Coleoptera, Hemiptera, Lepidoptera, Araneae, Odonata, Orthoptera, and Isoptera. The order included in insect pests are 5 orders namely Diptera, Hemiptera, Lepidoptera, Orthoptera, Isoptera, and included in natural enemies there were 3 orders namely the order of Odonata, Coleoptera, Araneae, while the order Hymenoptera is included into natural enemies and as pollinators and insects that dominated the Diptera order as much as 3223 and insect diversity index 1.0123733 had a medium benchmark value and an insect dominance index of 0.439025297 with a low benchmark value.

Keywords : Insect Diversity Index, Insect Dominance Index, Yellow Trap, Sunflower (Helianthus annuus L.)
\end{abstract}

\section{PENDAHULUAN}

Indonesia merupakan salah satu negara tropis sehingga terdapat berbagai tanaman lokal maupun tanaman introduksi yang dapat tumbuh secara baik, sebagai salah satu contohnya 
adalah tanaman bunga matahari. Bunga matahari yang bernama latin Helianthus annuus L. termasuk kedalam famili Asteraceae merupakan tanaman bunga introduksi yang berasal dari negara Amerika Utara dan mempunyai berbagai manfaat. Hasil produksi biji bunga matahari di Indonesia masih terbatas sehingga Indonesia harus melakukan impor untuk memenuhi kebutuhan, hal ini karena kurangnya pengetahuan petani dalam manfaat dan budidaya bunga matahari (Kartika, 2018). Maka dari itulah untuk menekan impor biji matahari perlu adanya peningkatan dalam budidaya bunga matahari supaya hasil produksi bunga matahari dapat meningkat untuk memenuhi kebutuhan di dalam negeri. Salah satu upaya untuk meningkatkan budidaya bunga matahari yaitu perlu diperhatikan dalam karakteristik bunga matahari atau syarat tumbuh yang sesuai, genotif yang bagus serta pengendalian Organisme Pengganggu Tanaman (OPT).

Serangan OPT dalam budidaya salah satunya yaitu serangga. Serangga merupakan hewan yang memiliki ciri berkaki enam (heksapoda) yang terbagi kedalam hewan atau serangga yang menguntungkan atau merugikan bagi tanaman budidaya. Serangga juga terbagi kedalam dua peran yaitu serangga yang memakan tumbuhan atau herbivora dan serangga yang memakan serangga lainnya atau karnivora. Serangga ditemukan hampir di semua ekosistem. Semakin banyak tempat dengan berbagai ekosistem maka terdapat jenis serangga yang beragam. Serangga yang berperan sebagai pemakan tanaman disebut hama, tetapi tidak semua serangga berbahaya bagi tanaman. Ada juga serangga berguna seperti serangga penyerbuk, pemakan bangkai, predator dan parasitoid (Siregar dkk., 2014).

Pengendalian serangga dapat dilakukan dengan teknik pemasangan perangkap atau jebakan untuk hama tanaman, salah satunya dengan menggunakan perangkap kuning (yellow trap) pada lahan budidaya tanaman. Yellow trap ini merupakan perangkap serangga yang ramah lingkungan serta sangat efektif dalam mengendalikan serangan serangga, tidak hanya dengan perangkap pengendalian juga apat dilakukan secara visual atau dilihat langsung dilapangan. Menurut Mas'ud (2011) menyatakan bahwa efektifitas penggunaan perangkap perekat warna kuning (Yellow Sticky Trap) dapat menangkap berbagai jenis serangga di areal pertanaman karena ketertarikan serangga terhadap warna kuning dari perangkap bukan semata-mata karena tertarik pada tanaman budidaya.

Tujuan penelitian ini yaitu untuk mengetahui keanekaragaman serangga, jenis dan peran serangga serta serangga yang mendominasi pada lahan budidaya yang menyerang tanaman bunga matahari (Helianthus annuus L.)

\section{METODE PENELITIAN}

Penelitian dilaksanakan di Kampung Sindang Sari, Desa Ciburial, Kecamatan Leles, Kabupaten Garut dari bulan Mei hingga Juli 2019. Ketinggian tempat 700 mdpl laut dengan nilai curah hujan $\mathrm{Q}=24,71 \%$ berdasarkan Schmidt dan Ferguson (1951) termasuk kedalam tipe curah hujan B yaitu basah.

Bahan yang digunakan dalam penelitian ini adalah alkohol $70 \%$ untuk mengawetkan serangga yang diamati secara visual, lem tikus, dan lahan penelitian bunga matahari (Helianthus annuus L.). Alat-alat yang digunakan dalam penelitian adalah botol $600 \mathrm{ml}$, scotlite berwarna kuning, gunting, botol plastik berukuran kecil, alat tulis, pinset, alat hitung (hand counter), karet (untuk mengikat plastik pada botol perangkap), kayu sebagai penyangga yellow trap (ajir), dan plastik.

Penelitian ini menggunakan metode kualitatif pada lahan penelitian dengan pemasangan perangkap yaitu yellow trap sebanyak 12 trap yang ditentukan polanya secara acak dan 
pengamatan secara visual saat dilapangan. Mengidentifikasi serangga hama atau serangga musuh alami serta menentukan serangga paling dominan pada lahan penelitian.

Indeks keanekaragaman serangga pada lahan tanaman bunga matahari dihitung dengan menggunakan indeks Shannon Wiener (H’) (Soegianto, 1994 dalam Hidayanti, 2016).

$$
\mathrm{H}^{\prime}=-\sum\left(\frac{n i}{N}\right)\left(\operatorname{In} \frac{n i}{N}\right)
$$

Keterangan:

$\mathrm{H}^{\prime}$ : indeks keanekaragaman jenis

$n i$ : Jumlah individu dari seluruh jenis

$\mathrm{N}$ : Jumlah total individu dari seluruh jenis

Hasil nilai keanekaragaman yang telah didapatkan, bisa dilihat sesuai dengan nilai tolak ukur sebagai berikut :
$\mathrm{H}^{\prime}<1,0$
: Keanekaragaman rendah
$1,0<\mathrm{H}^{\prime}<3,322$
: Keanekaragaman sedang
$\mathrm{H}^{\prime}>3,322$
: Keanekaragaman tinggi

Indeks dominasi pada suatu lahan tanaman bunga matahari dihitung menggunakan rumus Simpson (Ludwid dan Reynold, 1988 dalam Supriadi dkk,2015) yaitu :

Keterangan :

$$
\mathrm{C}=\sum\left(\frac{n i}{N}\right)^{2}
$$

$\mathrm{C}:$ Indeks dominasi

ni : Jumlah individu ke-i

$\mathrm{N}$ : Jumlah seluruh individu

Hasil nilai dominasi yang telah didapatkan, bisa dilihat sesuai dengan nilai tolak ukur sebagai berikut :

$0<\mathrm{C} \leq 0,5 \quad$ : Dominasi rendah

$0,5<\mathrm{C} \leq 0,75$ : Dominasi sedang

$0,75<\mathrm{C} \leq 1,0 \quad$ : Dominasi tinggi

\section{HASIL DAN PEMBAHASAN}

\section{Pengamatan Serangga dengan Yellow Trap}

Berdasarkan hasil penelitian pada tanaman bunga matahari dengan menggunakan perangkap kuning (yellow trap) didapatkan serangga dengan jumlah ordo sebanyak 9 ordo serangga. Ordo-ordo tersebut ialah ordo Diptera (Contoh: jenis-jenis lalat dan nyamuk), ordo Hymenoptera (Contoh: lebah dan semut), ordo Coleoptera (contoh: Kumbang dan tomcat), ordo Hemiptera (contoh: wereng daun, kepik, dan walang sangit), ordo Lepidoptera (contoh: ulat, ngengat atau kupu-kupu), ordo Araneae (contoh: laba- laba), ordo Odonata (contoh: capung), ordo Orthoptera (contoh: belalang), ordo Isoptera (contoh: Laron).

Perangkap kuning dapat menarik serangga yang menyerang pada tanaman bunga matahari dikarenakan serangga tertarik dengan warna yang menyerupai warna kelopak bunga, sesuai dengan penelitian Hakim, dkk (2016) Ketertarikan serangga terhadap warna kuning cenderung lebih tinggi dapat disebabkan adanya kemiripan warna polen bunga menjelang masak. 


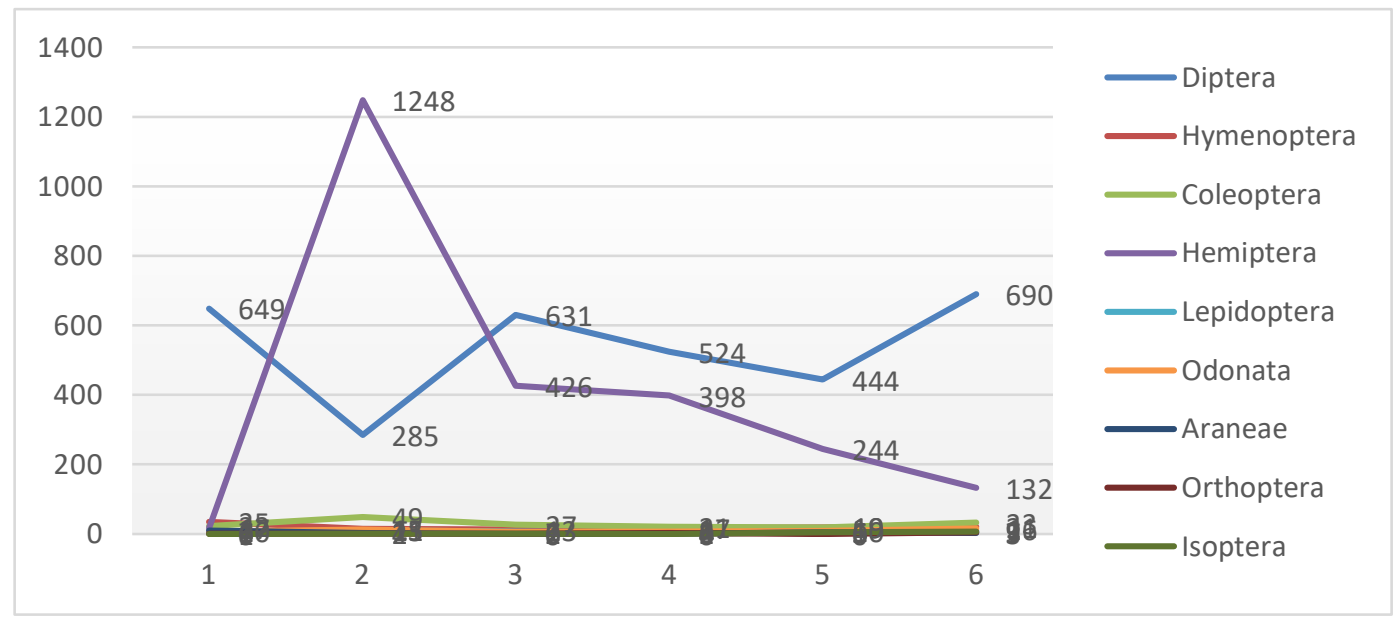

Gambar 1. Fluktuasi Keberadaan Serangga pada Lahan Penelitian Bunga Matahari (Helianthus annuus L.) dengan Yellow Trap

Berdasarkan pengamatan yang telah dilakukan didapatkan serangga yang terperangkap pada yellow trap bahwa pada (Gambar 1) di atas serangga yang jumlahnya paling tinggi selama enam kali pengamatan yaitu ordo Diptera (seperti nyamuk dan lalat) sebanyak 3223 serangga yang terperangkap pada yellow trap. Serangga muncul pada pengamatan pertama dan mencapai puncak populasi serangga pada pengamatan ke- 6 sebanyak 690 serangga. Menurut Borror (1996) bahwa ordo Diptera merupakan ordo yang memiliki anggota individu dan jenis terbesar dari serangga serta terdapat hampir dimana-mana, sesuai dengan penelitian Sulistya (2015). Berdasarkan hasil yang diperoleh dalam penelitian diketahui bahwa pada semua perlakuan yang menggunakan perangkap kuning dapat memerangkap dua jenis lalat buah yaitu Bactrocera dorsalis dan Bactrocera tau.

Keberadaan serangga yang pada ordo Hemiptera muncul pada pengamatan ke-1 sebayak 17 serangga dan mencapai puncak populasi pada pengamatan ke-2 yaitu sebanyak 1248 serangga, untuk serangga yang lainnya seperti Hymenoptera, Coleoptera, Lepidoptera, Odonata, Aranae, Orthoptera dan Isoptera tidak mengalami fluktuasi jumlah serangga yang signifikan.

\section{Indeks Keanekaragaman Serangga dengan Yellow Trap}

Keanekaragaman serangga yang menyerang pada bunga matahari dapat dilihat pada (Tabel 1), berdasarkan pengamatan bahwa serangga yang dapat terperangkap pada yellow trap beranekaragam dan dikelompokkan sesuai ordo serangga tersebut yaitu ordo Diptera, Hymenoptera, Coleoptera, Hemiptera, Araneae, Odonata, Lepidoptera, Orthoptera, dan Isoptera. Hal ini seperti pada penelitian Maesyaroh (2018) bahwa terdapatnya serangga yang beranekaragam dilahan percobaan dikarenakan kondisi lingkungan yang berbeda yang dipengaruhi oleh suhu, kelembaban, intensitas cahaya. Hasil perhitungan indeks keanekaragaman serangga yang menyerang pada tanaman bunga matahari (Helianthus annuus L.) dengan yellow trap dapat dilihat pada tabel 1 sebagai berikut ini : 
Tabel 1. Hasil Perhitungan Indeks Keanekaragaman dengan Yellow Trap

\begin{tabular}{lcccr}
\hline \multicolumn{1}{r}{ Ordo } & $\mathrm{ni}$ & $\mathrm{ni} / \mathrm{N}$ & $\mathrm{ln} \mathrm{ni} / \mathrm{N}$ & \multicolumn{1}{c}{$\mathrm{H}^{\prime}$} \\
\hline Diptera & 3223 & 0,5252608 & $-0,6438605$ & 0,3381946 \\
Hymenoptera & 120 & 0,0195567 & $-3,9344366$ & 0,0769447 \\
Coleoptera & 171 & 0,0278683 & $-3,5802648$ & 0,0997760 \\
Hemiptera & 2465 & 0,4017275 & $-0,9119813$ & 0,3663680 \\
Lepidoptera & 43 & 0,0070078 & $-4,9607282$ & 0,0347639 \\
Odonata & 60 & 0,0097784 & $-4,6275838$ & 0,0452502 \\
Araneae & 24 & 0,0039113 & $-5,5438745$ & 0,0216840 \\
Orthoptera & 14 & 0,0022816 & $-6,0828710$ & 0,0138788 \\
Isoptera & 16 & 0,0026076 & $-5,9493396$ & 0,0155133 \\
\hline $\mathrm{N}$ & 6136 & & & $\mathbf{1 , 0 1 2 3 7 3 3}$
\end{tabular}

Keterangan: $\mathrm{H}^{\prime}$ : indeks keanekaragaman jenis, $n i$ : Jumlah individu dari seluruh jenis, $\mathrm{N}$ : Jumlah total individu dari seluruh jenis

Berdasarkan tabel 1 diatas bahwa hasil perhitungan indeks keanekaragaman $\left[\mathrm{H}^{\prime}\right]$ serangga yang menyerang tanaman bunga matahari dan terperangkap pada yellow trap yaitu 1,0123733 dengan demikian nilai tolak ukur keanekaragamannya sedang. Menurut Aditama (2013) yang menyatakan bahwa keberadaan serangga di alam dipengaruhi oleh keberadaan faktor abiotik atau unsur iklim sebagai komponen suatu ekosistem meliputi suhu, intensitas cahaya, kelembaban udara. Menurut Jumar (2000) menyatakan bahwa kisaran suhu yang ideal bagi serangga berada pada rentan $15^{\circ} \mathrm{C}-45^{\circ} \mathrm{C}$ dengan suhu optimumnya yakni $25^{\circ} \mathrm{C}$. Pada suhu optimum umumnya serangga sangat melimpah karena kecenderungan untuk berkembang biak. Kemampuan serangga pada kisaran suhu optimum dapat meningkatkan angka reproduktif serta menekan angka kematian dini pada serangga.

\section{Indeks Dominasi Serangga pada Yellow Trap}

Dominasi serangga dapat digunakan untuk mengetahui sejauh mana suatu spesies atau genus serangga mendominasi kelompok suatu komunitas lainnya, dapat dihitung dengan menggunakan rumus simpson seperti pada tabel 2 di bawah ini :

Tabel 2. Dominasi Serangga yang Terperangkap pada Yellow Trap

\begin{tabular}{lccc}
\hline \multicolumn{1}{r}{ Ordo } & $\mathrm{ni}$ & $\mathrm{ni} / \mathrm{N}$ & $\mathrm{C}$ \\
\hline Diptera & 3223 & 0,525517691 & 0,276168844 \\
Hymenoptera & 117 & 0,019077124 & 0,000363937 \\
Coleoptera & 171 & 0,027881950 & 0,000777403 \\
Hemiptera & 2465 & 0,401924018 & 0,161542916 \\
Lepidoptera & 43 & 0,007011251 & 0,000049158 \\
Odonata & 60 & 0,009783140 & 0,000095710 \\
Araneae & 24 & 0,003913256 & 0,000015314 \\
Orthoptera & 14 & 0,002282733 & 0,000005211 \\
Isoptera & 16 & 0,002608837 & 0,000006806 \\
\hline $\mathrm{N}$ & 6133 & & 0,439025297 \\
\hline
\end{tabular}

Keterangan: $\mathrm{C}=$ Indeks dominasi, $n i=$ Jumlah individu dari seluruh jenis, $\mathrm{N}=$ Jumlah total individu dari seluruh jenis. 
Berdasarkan tabel 2 bahwa hasil perhitungan dominasi serangga yaitu 0,439025297 maka dengan demikian nilai tolak ukur untuk dominasi serangga rendah. Menurut Odum (1993) yang menyatakan bahwa nilai indeks dominansi yang tinggi menyatakan konsentrasi dominansi yang tinggi (ada individu yang mendominansi), sebaliknya nilai indeks dominansi yang rendah menyatakan konsentrasi yang rendah (tidak ada yang dominan).

\section{Pengamatan Serangga secara Visual di Lahan Penelitian}

Pengamatan dilakukan dengan menghitung serangga yang terdapat di lahan penelitian bunga matahari (Helianthus annuus L.) selanjutnya dikelompokkan sesuai dengan ordo dari serangga tersebut. Serangga yang didapatkan di lahan penelitian dapat dilihat pada (Gambar 2) berikut ini :

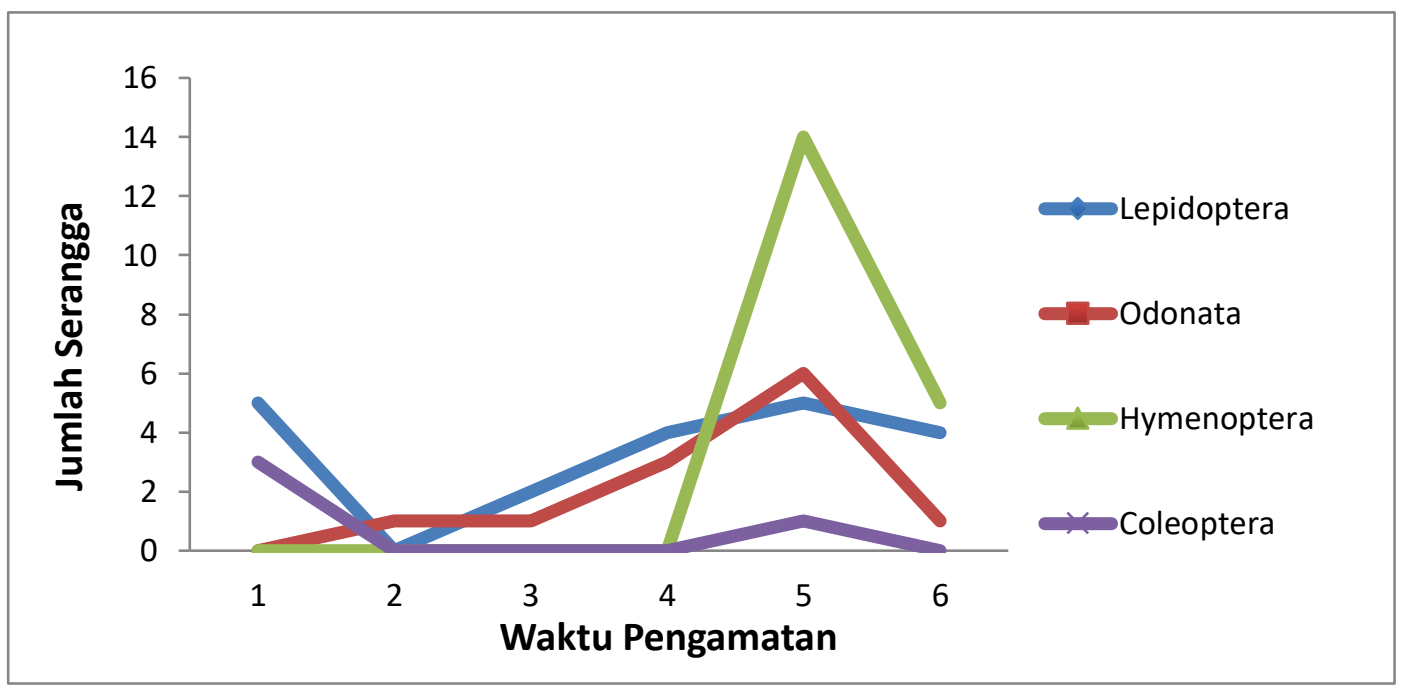

Gambar 2. Fluktuasi Keberadaan Serangga yang Menyerang pada Tanaman Bunga Matahari (Helianthus annuus L.) secara visual di Lahan Penelitian

Berdasarkan hasil pengamatan yang telah dilakukan secara visual di lahan penelitian bahwa didapatkan empat ordo serangga yaitu Lepidoptera, Odonata, Hymenoptera dan Coleoptera. Serangga yang paling banyak didapatkan yaitu ordo Lepidoptera (ulat, ngengat atau kupu-kupu) sebanyak 20 serangga, muncul pada pengamatan ke-1 dan mencapai puncak populasi pada pengamatan ke- 5 sebanyak 5 serangga.

\section{Indeks Keanekaragaman Serangga secara Visual}

Indeks keanekaragaman serangga dapat dihitung dengan menggunakan rumus Shannon Wiener, dengan demikian hasil perhitungan keanekaragaman serangga dapat dilihat pada (tabel 3).

Dilihat dari tabel 3 bahwa hasil perhitungan indeks keanekaragaman [H'] yang dilakukan secara visual langsung di lahan penelitian yaitu 1,257823 dengan demikian nilai tolak ukur indek keanekaragamannya sedang. Menurut Untung (2001) keanekaragaman jenis serangga akan selalu mengikuti keadaan ekosistem yang ditempatinya sebab ekosistem tidak akan sama dari waktu ke waktu dan akan cenderung berubah apabila lingkungan fisiknya turut berubah dan sesuai penelitian Sulistya (2015) bahwa Tinggi rendahnya indeks keragaman serangga ini dipengaruhi oleh faktor iklim. Menurut Sunjaya (1970) bahwa apabila kelembaban tinggi, maka proses metaboisme serangga akan cepat dan perkembangan jauh 
lebih pendek, tetapi bila kadar air tubuhnya berkurang, kelembaban rendah maka akan menghambat proses metabolisme yang berarti memperlambat perkembangannya. Pada umumnya serangga memiliki kandungan air dalam tubuhnya sekitar 50-90\%, kondisi ini dapat dipertahankan jika kelembaban lingkungan berkisar diantara nilai tersebut (Susanto, 2000).

Tabel 3. Hasil Perhitungan Indeks Keanekaragaman secara Visual di Lahan Penelitian

\begin{tabular}{lcccc}
\hline \multicolumn{1}{c}{ Ordo } & ni & ni/N & $\ln$ ni/N & $\mathrm{H}^{\prime}$ \\
\hline Lepidoptera & 20 & 0,363636 & $-1,011601$ & 0,367855 \\
Odonata & 12 & 0,218182 & $-1,522427$ & 0,332166 \\
Hymenoptera & 19 & 0,345455 & $-1,062894$ & 0,367182 \\
Coleoptera & 4 & 0,072727 & $-2,621039$ & 0,190621 \\
\hline \multicolumn{1}{c}{$\mathrm{N}$} & 55 & & & $\mathbf{1 , 2 5 7 8 2 3}$ \\
\hline
\end{tabular}

Keterangan: $\mathrm{H}^{\prime}$ = indeks keanekaragaman jenis, $n i=$ Jumlah individu dari seluruh jenis $\mathrm{N}=$ Jumlah total individu dari seluruh jenis

\section{Indeks Dominasi Serangga secara Visual}

Indeks dominasi serangga pada pengamatan secara visual dihitung dengan mengunakkan rumus Simpons sebagai berikut ini pada (tabel 4) :

Tabel 4. Dominasi Serangga yang didapatkan secara Visual di Lahan Penelitian

\begin{tabular}{lccc}
\hline \multicolumn{1}{r}{ Ordo } & ni & ni/N & $\mathrm{C}$ \\
\hline Lepidoptera & 20 & 0,363636 & 0,132231 \\
Odonata & 12 & 0,218182 & 0,047603 \\
Hymenoptera & 19 & 0,345455 & 0,119339 \\
Coleoptera & 4 & 0,072727 & 0,005289 \\
\hline \multicolumn{1}{c}{$\mathrm{N}$} & 55 & & $\mathbf{0 , 3 0 4 4 6 3}$ \\
\hline
\end{tabular}

Keterangan:

$\mathrm{C}=$ Indeks dominasi

$n i=$ Jumlah individu dari seluruh jenis,

$\mathrm{N}=$ Jumlah total individu dari seluruh jenis

Berdasarkan tabel 4 bahwa hasil dominasi serangga yang dilakukan secara visual yaitu 0,304463 dengan nilai tolak ukur rendah. Maka dengan demikian bahwa kodisi lingkungan tersebut dalam keadaan stabil dan tidak terjadi tekanan ekologis terhadap biota di habitat tersebut. Menurut Munthe (2012) Penentuan nilai indeks dominasi (C) adalah dengan cara metode perhitungan dengan rumus indeks dominasi Simpson dengan ketentuan jika nilai indeks dominasi $0<\mathrm{C} \leq 0,5$ maka tidak ada genus yang mendominasi dan jika nilai indeks dominasi $0,5<\mathrm{C}<1$ maka terdapat genus yang mendominasi.

\section{Peran Serangga}

Peranan serangga terbagi kedalam dua peran yaitu serangga yang dapat menguntungkan manusia atau serangga yang dapat merugikan manusia. Serangga yang berperan sebagai serangga yang menguntungkan yaitu seperti musuh alami (predator, Parasitoid), serangga penyerbuk (Polinator) dan penghasil produk-produk perdagangan, dan 
lain-lain. Sedangkan serangga yang dapat merugikan manusia seperti serangga yang berperan sebagai hama yang menyerang pada tanaman pertanian.

Tabel 5. Identifikasi Peran Serangga dengan Menggunakan Yellow Trap

\begin{tabular}{|c|c|c|c|}
\hline Ordo & $\Sigma$ & Total & Peran Serangga \\
\hline \multicolumn{4}{|l|}{ Diptera } \\
\hline Muscidae & 343 & \multirow{3}{*}{3223} & \multirow{3}{*}{ Hama } \\
\hline Tephritidae & 1720 & & \\
\hline Culicidae & 1160 & & \\
\hline \multicolumn{4}{|l|}{ Hemiptera } \\
\hline Aleyrodidae & 1241 & \multirow{4}{*}{2465} & \multirow{4}{*}{ Hama } \\
\hline Alydidae & 12 & & \\
\hline Cicadellidaae & 1211 & & \\
\hline Pentatomidae & 1 & & \\
\hline \multicolumn{4}{|l|}{ Lepidoptera } \\
\hline Noctuidae & 43 & 43 & Hama \\
\hline \multicolumn{4}{|l|}{ Orthoptera } \\
\hline Acrididae & 14 & 14 & Hama \\
\hline \multicolumn{4}{|l|}{ Isoptera } \\
\hline Termitidae & 16 & 16 & Hama \\
\hline \multicolumn{4}{|l|}{ Hymenoptera } \\
\hline Formicidae & 57 & \multirow{2}{*}{120} & Musuh Alami \\
\hline Apidae & 63 & & Penyerbuk \\
\hline \multicolumn{4}{|l|}{ Coleoptera } \\
\hline Coccinellidae & 163 & \multirow{2}{*}{171} & \multirow{2}{*}{ Musuh Alami } \\
\hline Staphylinidae & 8 & & \\
\hline \multicolumn{4}{|l|}{ Odonata } \\
\hline Cordiliidae & 60 & 60 & Musuh Alami \\
\hline Araneae & 24 & 24 & Musuh Alami \\
\hline
\end{tabular}

Berdasarkan pengamatan pada tabel 5 bahwa terdapat serangga yang didominasi dengan serangga yang berperan sebagai hama dibandingkan dengan serangga yang berperan sebagai musuh alami. Serangga hama yang didapat ada lima ordo serangga yaitu ordo diptera, hemiptera, lepidoptera, orthoptera, dan isopteran. Serangga hama didominasi oleh ordo Diptera sebanyak 3223 serangga dengan famili Muscidae 343 serangga, Tephritidae 1720 serangga dan Culicidae 1160 serangga. Musuh alami didapatkan empat ordo serangga yaitu ordo hymenoptera, coleoptera, odonata, dan araneae dan musuh alami yang mendominasi adalah ordo coleoptera sebanyak 171 serangga dengan famili Coccinellidae 163 serangga dan Staphylinidae 8 serangga, sedangkan untuk ordo Hymenoptera terbagi kedalam dua peran yaitu serangga dengan famili Formicidae berperan sebagai musuh alami dengan jumlah serangga sebanyak 57 serangga dan famili Apidae berperan sebagai serangga penyerbuk sebanyak 63 serangga. Serangga yang didapatkan secara visual dilahan penelitian adalah sebagai berikut : 
Agritrop, Vol. 18 (1): 88 - 97

Tabel 6. Identifikasi Peran Serangga secara Visual di Lahan Penelitian

\begin{tabular}{lcc}
\hline \multicolumn{1}{c}{ Ordo } & $\Sigma$ & Peran Serangga \\
\hline Lepidoptera & & \\
Noctuidae & 18 & Hama \\
Lymantriidae & 2 & Musuh Alami \\
Odonata & 12 & Penyerbuk \\
$\begin{array}{l}\text { Cordiliidae } \\
\text { Hymenoptera }\end{array}$ & & \\
$\begin{array}{l}\text { Apidae } \\
\text { Coleoptera }\end{array}$ & 19 & Musuh Alami \\
Coccinellidae & 4 & \\
\hline
\end{tabular}

Berdasarkan tabel 6 bahwa serangga yang didapatkan terdapat satu ordo serbagai hama yaitu ordo Lepidoptera (ulat, ngengat atau kupu-kupu) sebanyak 20 serangga, salah satu serangga yang paling banyak menyerang adalah famili Noctuidae seperti ulat grayak (Spodoptera litura) yang menyerang daun tanaman bunga matahari (Helianthus annuus L.). Spodoptera litura (Lepidoptera) merupakan hama polyphagous yang menyerang banyak jenis tanaman seperti jagung, kedelai, kapas, tomat dan telah dilaporkan mencapai 150 spesies yang tersebar di seluruh belahan dunia (Kranthi et al., 2012). Menurut Singh et al., (2015) S. litura juga menyerang kacang tanah, jagung, dan tanaman hias. Sedangkan serangga yang berperan sebagai serangga musuh alami terdapat tiga ordo yaitu ordo odonata sebanyak 12 serangga dan coleoptera sebanyak 4 serangga.

Ordo hymenoptera seperti lebah (famili Apidae) termasuk kedalam serangga yang berperan kedalam serangga penyerbuk (pollinator). Hal ini sesuai dengan penelitian Falahudin (2015) bahwa lebah yang termasuk dalam Ordo hymenoptera memiliki kemampuan untuk membantu penyerbukan tumbuhan, karena tubuh lebah ditutupi bulu-bulu halus yang berguna untuk menangkap serbuk sari yang diperoleh dari bunga.

Serangga yang berperan sebagai hama merupakan serangga yang dapat merusak tanaman budidaya bunga matahari (Helianthus annuus L.) sehingga dapat menurunkan kualitas dan hasil produksi pada tanaman tersebut. Keberadaan serangga hama dalam suatu ekosistem pertanaman akan memengaruhi kegiatan budidaya karena secara langsung akan menurunkan kualitas dan kuantitas produk yang dihasilkan dan jika kegiatan pengendalian tidak dilakukan maka kegiatan budidaya akan mengalami kerugian. Kerugian yang akan dihadapi merupakan berbagai faktor yang berpengaruh terhadap pertumbuhan tanaman seperti tinggi rendahnya serangan hama, oleh karena itu pengendalian hama penting untuk dilakukan (Dadang dkk., 2007).

Salah satu serangga yang dapat menguntungkan bagi budidaya tanaman yaitu serangga yang berperan sebagai musuh alami seperti serangga predator dan parasitoid. Kegunaan musuh alami pada tanaman bunga matahari akan mengurangi dampak dari penyerangan hama pada tanaman sehingga mengurangi kerugian yang disebabkan oleh hama seperti turunnya kualtias dan kuantitas pada tanaman bunga matahari (Helianthus annuus L.). Menurut Untung (2006) Serangga predator merupakan serangga yang memakan, membunuh atau memangsa serangga lain, sedangkan menurut Agung (2014), menyatakan bahwa serangga predator merupakan faktor penting dalam menjaga keseimbangan ekosistem dan juga sebagai pengendali hayati atau musuh alami hama. 


\section{Kesimpulan}

\section{KESIMPULAN}

Berdasarkan penelitian yang sudah dilakukan dengan melihat keanekaragaman serangga yang menyerang pada tanaman bunga matahari (Helianthus annuus L.) maka dapat diambil kesimpulan sebagai berikut :

1. Serangga yang didapatkan pada tanaman bunga matahari (Helianthus annuus L.) terdapat 9 ordo serangga yaitu ordo diptera, hymenoptera, coleoptera, hemiptera, lepidoptera, araneae, odonata, orthoptera, isoptera. Serangga pada yellow trap didominasi oleh ordo diptera (3223) sedangkan pada pengamatan visual didominasi oleh lepidoptera (20) serangga.

2. Serangga yang termasuk hama terdapat 5 ordo yaitu diptera, hemiptera, lepidoptera, orthoptera, isoptera, dan yang termasuk kedalam musuh alami terdapat 3 ordo yaitu ordo odonata, coleoptera, araneae, sedangkan ordo hymenoptera termasuk kedalam musuh alami dan sebagai serangga penyerbuk (pollinator). Indeks keanekaragaman serangga sedang dan indeks dominasi serangga memiliki nilai tolak ukur rendah.

\section{Saran}

Perlu dilakukannya penelitian lanjutan mengenai keanekaragaman serangga pada tanaman bunga matahari secara lebih spesifik sampai ke spesies dan memperluas daerah pengamatan yang belum diteliti untuk mengetahui perkembangan keanekaragaman serangga yang lebih luas.

\section{DAFTAR PUSTAKA}

Aditama CR, dan Kurniawan N. 2013. Struktur komunitas serangga nokturnal areal pertanian padi organik pada musim penghujan di Kecamatan Lawang, Kabupaten Malang. Jurnal Biotropika. 1(4) : 186-190.

Agung, S. A. P., Ibrohim, dan Tuarita, H. 2014. Kajian Struktur Dan Komposisi Komunikas Serangga Predator Yang Berpotensi Sebagai Agen Pengendali Hayati Di Perkebunan Kopis Desa Bangelan Kecamatan Wonosari Kabupaten Malang. Malang: Universitas Negeri Malang.

Borror, D. J. Triplehorn C.A, dan Johnson, NF. 1996. Pengenalan Pelajaran Serangga Edisi Keenam, Terjemah oleh Soetiyono Partosoedjono. Yogyakarta: Gadjah Mada University Press.

Dadang, G Suastika, dan RS Dewi. 2007. Hama dan Penyakit Tanaman Jarak Pagar (Jatropha curcas). Surfactant and Bioenergy Research Center, Bogor.

Falahudin, I., Pane, E. R., \& Mawar, E. (2015). Identifikasi Serangga Ordo Coleoptera Pada Tanaman Mentimun ( Cucumis Sativus L ) Di Desa Tirta Mulya Kecamatan. Jurnal Biota, 1(1), 9-15.

Jumar. (2000). Etimologi Pertanian. Jakarta: PT Renika Cipta.

Kartika, M. M. (2018). Korelasi dan Sidik Lintas pada Hasil dan Komponen Hasil bunga Matahari (Helianthus annuus L.). Fakultas Pertanian, Universitas Brawijaya, Malang.

Kranthi, K.R., D.R., Jadhav, R.R. Wanjari, R. Ali. 2012. Insecticide Resistansce in Five Major Insect Pests of Catton in India. J.Crops Protection, 21:449-460. 
Hakim, L., Surya, E., \& Muis, A. (2016). Pengendalian Alternatif Hama Serangga Sayuran Dengan Menggunakan Perangkap Kertas Alternative Control Of Insect In Vagatabel Crops Using Trapping Paper Media. Jurnal Agro, III(2), 21-33.

Hidayanti, F. K. (2016). Keanekaragaman Serangga Aerial di Arboretrum Sumber Brantas dan Lahan Pertanian Kentang Kecamatan Bumiaji Kota Batu. Skripsi. Jurusan Biologi, Fakultas Sains dan Teknologi, Universitas Islam Negeri (UIN) Maulana Malik Ibrahum. Malang.

Maesyaroh, S. S., Dewi, T. K., Tustiyani, I., \& Mutakin, J. (2018). Keberadaan dan Keanekaragaman Serangga pada Tanaman Jeruk Siam (Citrus nobilis L.). Jurnal Pertanian 9 (2), 115-121.

Mas'ud A., 2011, Efektifitas Trap Warna Ter5hadap Keberadaan Serangga Pada Pertanaman Budidaya Cabai di Kelurahan Sulahamadaha Pulau Ternate. Jurusan PMIPA FKIP Universitas Kairun Ternate. Ekologi Ternate, 159-165 (2011).

Munthe, Y. V., \& Aryawati, R. (2012). Struktur Komunitas dan Sebaran Fitoplankton di Perairan Sungsang Sumatera Selatan. Maspari Journal, 04(1), 122-130.

Odum, E. P. 1993. Dasar-Dasar Ekologi. Edisi Ketiga. Gajah mada University Press. Jogjakarta. Hlm. 134-162.

Singh, I.K., P.R. Ragesh, G. Satish, K.S. Ashok. 2015. Oviposition behavior of tobacco caterpillar Spodoptera litura Fab. (Lepidoptera : Noctuidae) on Different Host Plant. J. Entomology and Zoology, 3(3): 40-44. India.

Siregar, A. S., Bakti, D., \& Zahara, F. (2014). Keanekaragaman Jenis Serangga Di Berbagai Tipe Lahan Sawah. Jurnal Online Agroekoteknologi Vol.2, No.4, 1640 - 1647.

Sulistya. (2015). Efektivitas Model Perangkap Lalat Buah Pada Pertanaman Jambu Biji Merah Di Desa Sumberagung Bantul. Agros, 17(2), 228-237.

Sunjaya, P. 1970. Dasar -dasar Ekologi Serangga. IPB. Bogor 135 p. Supriadi., Romadhon, A., Farid.,A. 2015. Struktur Komunitas Mangrove di Desa Martajasah Kabupaten Bangkalan, Vol 3 (1).

Susanto, P. 2000. Pengantar Ekologi Hewan. Jakarta: Dirjen Pendidikan Tingkat Departemen Nasional. Susilo, F. X. 2007. Pengendalian Hayati dengan Memberdayakan Musuh Alami Hama Tanaman. Graha Ilmu, Yogyakarta.

Untung,K. 2001. Pengantar Pengelolaan Hama Terpadu. UGM Press. Yogyakarta.

Untung, K. 2006. Pengantar Pengolahan Hama terpadu. Yogyakarta : Gadjah Mada Universyty Press 